\title{
Determination of the Moisture and Oil Thermal Diffusivity Coefficients in Breadfruit (Artocarpus altilis) During Vacuum Frying
}

\author{
Diofanor Acevedo Correa ${ }^{\# 1}$, Luis Alberto Gallo-García ${ }^{\# 2}$, Kevin José González-Morelo ${ }^{\# 3}$ \\ ${ }^{\#}$ Faculty of Engineering, Food Engineering program, Research Group NUSCA, University of Cartagena \\ Av. El Consulado, St. 30 No. 48-152. Colombia. \\ 1diofanor3000@gmail.com; ${ }^{2}$ lgallog1992@hotmail.com; ${ }^{3}$ kevinjgonza@hotmail.com.
}

\begin{abstract}
The objective of this research was to determinate the moisture and oil thermal diffusivity coefficients in the breadfruit vacuum frying in control, blanched and coated samples. Mass transfer coefficients were determined from the graphs of dimensional temperature and moisture content ratios vs. time, and the specific oil absorption rate was calculated using a first-order kinetic model.It was observed that the diffusion coefficient increased with increasing temperatures for all treatments.For coated samples, the specific oil absorption rate increased with temperature. In this study, it was reported that the treatment that reported the greatest diffusion $\mathbf{E}_{\mathrm{a}}$ was pectin-coated.
\end{abstract}

Keyword-Mass Transfer, kinetic, activation energy, Fick's law.

\section{INTRODUCTION}

The bread tree (Artocarpus altilis) is a species belonging to the genus Artocarpus, within the tribe of Artocarpeae, from the Moraceae family with hundreds of varieties of trees distributed from Southeast Asia to Polynesia, through Oceania.The anthropic action has distributed the species throughout all tropical areas of the region, especially the Antilles[1].This is a fruit that is generally consumed on the San Andres Island in fried or cooked form. It is part of the tourist gastronomy of this archipelago since it is offered to the visitors as an accompaniment to the typical dishes. It is a fruit with a high carbohydrate content (27.82\%) and a high percentage of moisture $(75 \%)$.

Food products contain high moisture content, which is partially or totally eliminated during dehydration. Drying and frying of food materials involves internal and external heat and mass transfer processes. The relative importance of these resistances varies significantly in the different dehydration processes[2]. The governance equations of a transport model describe the physical phenomena that occur within the domain of the solution. The interaction of the solution domain with the external environment is expressed by the boundary conditions. Therefore, various thermal food processes can be modelled using the same set of steering equations, butvarying the boundary conditions (e.g. frying and drying with hot air). Therefore, it is extremely important to have appropriate contour conditions that are representative for accurate prediction [3].

Moisture diffusivity is identified by adjusting the calculated experimental moisture contents, using an appropriate Fick model with specific boundary conditions representing the water transport in the food system studied[4]. This is an important physical transport property that is useful in the engineering analysis of basic food processing operations such as drying and frying. Diffusion phenomena are extremely complex, theoretical prediction of moisture diffusivity is difficult due to the structure and content of water and variable chemistry of each foodstuff. Therefore, it is necessary to obtain these data through experimental procedures[5].

Cranck[6], gives an excellent overview of mass transfer models based on Fick's diffusion differential equation through experimental data. It is common practice to describe full mass transfer with the same equation used for diffusion and to take the correction for all secondary types of mass transfer by simply replacing the diffusion coefficient with an effective diffusion coefficient[7].Demirkolet al.,[8] published their researches on the determination of moisture diffusivity of a biscuit baked at different temperatures in the oven. Fick's second equation was solved analytically with a finite convection mass transfer resistance on the surface. From the slopes of the experimental drying curves, they calculated the diffusivity of humidity.These researchers concluded that the effective diffusivity of biscuit moisture increased with progress in cooking time, and as the temperature increased. Simal et al., [9] also applied an Arrhenius equation to determine the variation of kiwi fruit diffusion coefficient as a function of temperature during drying. Diffusion coefficients values changed from $3 \times 10^{-10}$ (at $30^{\circ} \mathrm{C}$ ) to $17.21 \times 10^{-10} \mathrm{~m}^{2} \mathrm{~s}^{-1}\left(\right.$ at $\left.90^{\circ} \mathrm{C}\right)$. 
The simultaneous transfer of heat and mass during immersion frying promotes a series of chemical changes such as water loss, crust formation, starch gelatinization, aromatization and colour change through Maillard reactions, hydrolysis or oxidation, oil absorption and oil polymerization[10].On the other hand, oil absorption is one of the most important parameters of the quality of fried foods, which is incompatible with recent trends towards healthier foods and low-fat products[11]. Based on the above mechanisms, several strategies have been developed to reduce oil absorption. Pre-frying treatments such as hot air drying have been used.

One promising technology that has proven its potential for producing low-fat snacks is vacuum frying. Vacuum frying is a frying process, which is carried out in a closed system, under pressures well below atmospheric levels (preferably below 7000Pa), which makes it possible to substantially reduce the boiling point of the water, and therefore the frying temperature.

In recent years, several procedures have been proposed to reduce the amount of oil absorbed in French fries. Rubnov and Sagu[12] added fructose for a restructured potato product that resulted in a change in surface properties, with a reduction in oil absorbed after frying. Also the immersion of potato slices in $\mathrm{NaCl}$ solutions reduced the absorption of oil by $15 \%$ in potato chips after frying.Vacuum frying can also be an option to obtain breadfruit with low oil content by modifying the desired texture and flavour characteristics, since the surface properties of the fruit are more important for fat absorption, the application of suitable coatings is a promising route to reduce the oil content[13].There are many options available to reduce fat absorption by applying starchbased coatings or edible films. For example, Williams and Mittal[14] used Gellam gum for layer samples so that the resulting film reduced oil absorption during frying. In view of the above, the objective of this research was to determine the moisture and oil thermal diffusivity coefficients in vacuum breadfruit frying under pretreatment conditions.

\section{A. Raw material}

\section{MATERIALS AND METHODS}

Breadfruits (Artocarpus communis) and palm oil were purchased at a local supermarket in the city of Cartagena de Indias (Colombia). The fruits were selected taking into account the size and that they did not present damages by manipulation. The fruits were washed and disinfected, then cut into a flat sheet with dimensions of $(0.025 \times 0.003 \times 0.03 \mathrm{~m})$ for further analysis.

\section{B. Pre-treatments}

After the preparation of the fruits, they were divided into three blocks; the first block was blanched in water for 2 minutes at $95^{\circ} \mathrm{C}$ in a water bath WNB (Germany) with a capacity of $7 \mathrm{~L}$, connected to a power supply of $220 \mathrm{~V}$ and dimensions of $240 \times 210 \times 140 \mathrm{~mm}$, which has digital temperature and time control. Immediately afterwards the samples were cooled in water at room temperature for 20 s to prevent softening. The second block was coated with $1.2 \% \mathrm{w} \mathrm{v}^{-1}$ pectin in a solution of distilled water, stirred and heated to $60{ }^{\circ} \mathrm{C}$ to homogenize this polymer. The third block was the control, to which no pre-treatment was performed.

\section{Vacuum frying conditions}

The breadfruit slices were fried in a Gastrovac ${ }^{\mathrm{TM}}$ Vacuum Cooking and Impregnation System (International Cooking Concepts, Barcelona, Spain) with the measures: $0.04 \times 0.026 \times 0.046 \mathrm{~m}$, maximum capacity of $10.5 \mathrm{~L}$ and voltage $220 \mathrm{~V}$. The maximum vacuum pressure used in the equipment was $30 \mathrm{kPa}$. Frying temperatures of $120{ }^{\circ} \mathrm{C}, 130{ }^{\circ} \mathrm{C}$ and $140{ }^{\circ} \mathrm{C}$ were used. The frying times were in the range of $30 \mathrm{~s}$ to $300 \mathrm{~s}$, established by preliminary tests. The ratio of the product/oil was $1: 10 \mathrm{w} \mathrm{v}^{-1}$. First, the oil was heated to the desired temperature, the breadfruit slices samples were placed in a stainless steel basket, the lid was closed and the vacuum pump was activated. When the equipment reached maximum pressure, the basket was immersed in the hot oil. Once the desired frying time was reached, the basket was raised and the pump was left on for $15 \mathrm{~s}$, then the vacuum was broken and the equipment was turned off to remove the samples. Breadfruit slices were placed in a basket of metal mesh and placed in a desiccator for $10 \mathrm{~min}$, once the frying was finished, the respective analyses were performed.

\section{Moisture and oil content analysis}

The moisture content of the breadfruit was made by drying at $105 \pm 1{ }^{\circ} \mathrm{C}$ to constant weight, the determination of the oil content was performed by Soxhlet extraction[15]. All assays were performed in triplicate.

\section{E. Determination of diffusivity coefficient}

The second law of the Fick diffusion equation was used to adjust the experimental frying data for the determination of moisture diffusivity coefficients [16], Eq. 1.

$\frac{\partial X}{\partial t}=D_{\text {eff }} \frac{\partial^{2} X}{\partial X^{2}}$ 
The diffusion solution (Eq. 1) for the plate geometry is solved by the Eq. 2

$\frac{X-X_{\infty}}{X_{0}-X_{\infty}}=\frac{8}{\pi^{2}} \sum_{n=0}^{\infty} \frac{1}{(2 n+1)^{2}} \exp \left[-(2 n+1)^{2} \frac{\pi^{2} D_{\text {eff }}}{L^{2}}\right]$

The slope was determined by plotting $\ln \left(\mathrm{X}-\mathrm{X}_{\infty}\right) /\left(\mathrm{X}-\mathrm{X}_{\infty}\right)$ against time according to Eq. (3)

slope $=-\frac{\pi^{2} D_{\text {eff }}}{4 L^{2}}$

\section{F. Diffusion activation energy calculus}

The dependence of the moisture diffusivity as a function of temperature is generally described by an Arrhenius-type relationship, Eq. 4.

$D_{\text {eff }}=D_{0} \exp \left(\frac{-E_{a}}{R(T+273.15)}\right)$

Where $\mathrm{D}_{0}$ is the pre-exponential factor of the Arrhenius equation in $\mathrm{m}^{2} \mathrm{~s}^{-1}$, Ea is the activation energy in $\mathrm{kJ}$ $\mathrm{mol}^{-1}, \mathrm{R}$ is the universal gas constant in $\mathrm{kJ} \mathrm{mol}^{-1} \mathrm{~K}^{-1}$, and $\mathrm{T}$ is the temperature in ${ }^{\circ} \mathrm{C}$.

\section{G. Oil-uptake kinetics}

A first-order kinetic model proposed by Krokida et al., [17] was used, where k represents the specific oil absorptionrate, $\mathrm{O}_{\mathrm{eq}}$ is the equilibrium oil content. At $\mathrm{t}=0$, the oil content is zero, and at greater times, the oil content becomes the equilibrium value.

$O=O_{e q}(1-\exp (-k t))$

The ratio of the variation of the oil content in equilibrium with the frying temperature $\mathrm{T}$ was used to describe an Arrhenius type relationship having the form:

$O_{e q}=A \exp \left(E_{a} / R T\right)$

Where Ea is the activation energy, $\mathrm{R}$ is the gas constant and $\mathrm{A}$ is the pre-exponential factor associated with the shock factor in terms of absolute reaction rates.

\section{H. Statistical analysis}

An analysis of the variance (ANOVA) was performed by means of. Statgraphics (Statgraphics Centurion Version 16.1.15, Chicago, EE. UU) was used for data analysis[18]. The level of statistical significance was 5\%. All experiments were performed in triplicate.

\section{RESULTS AND DISCUSSIONS}

Fig. 1-3 shows the dimensionless ratio of moisture concentration vs. time, obtained during vacuum breadfruit frying. The slopes of the linear sections of these graphs were obtained by means of linear regression analysis. In control, blanched and pectin-coated samples, it was observed that as the frying temperature increased, the moisture content decreased. It is also detailed that the moisture loss rate of food increased with time and frying temperature. It was also evidenced that the sample coated and processed at higher temperatures showed higher moisture content, similar to that reported by Guzmán et al.,[19] in fried potatoes coated with pectin.

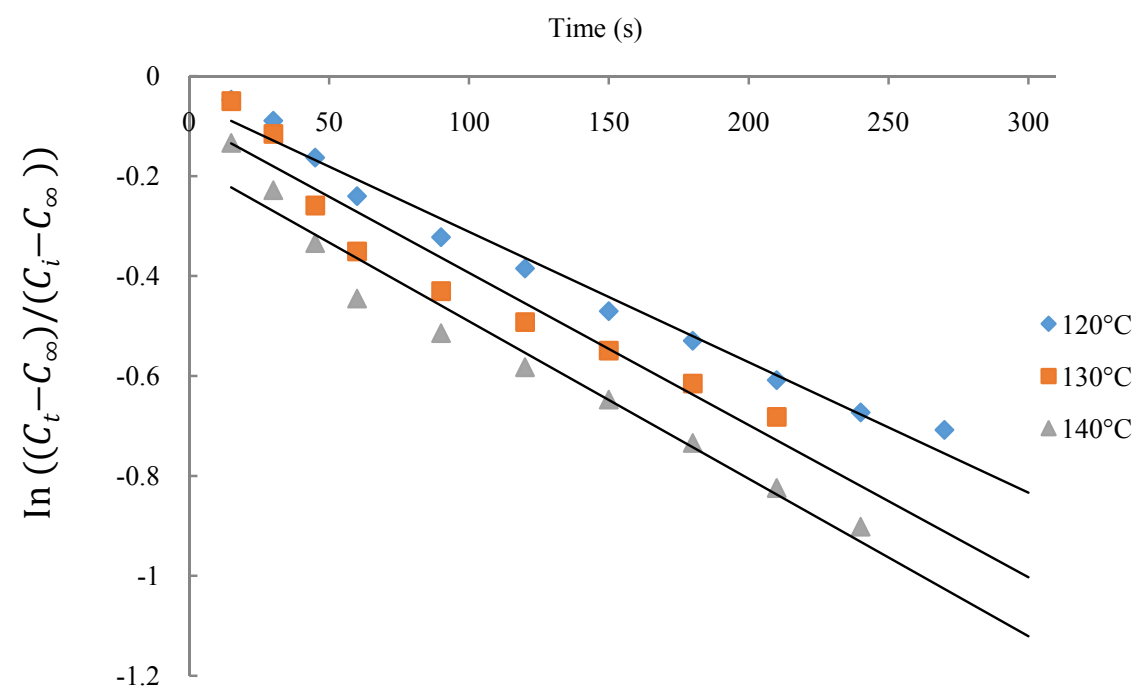

Fig. 1. Linear section of the dimensionless relation moisture vs. time in coating samples. 


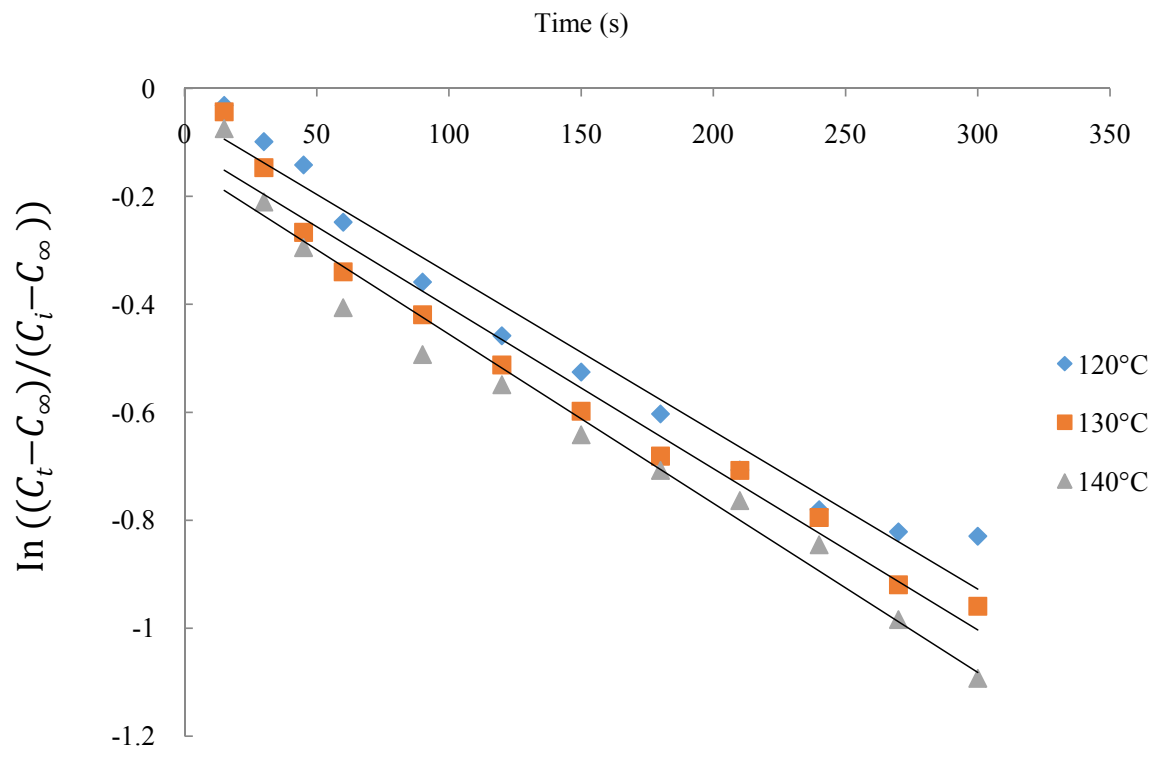

Fig 2. Linear section of the dimensionless relation Moisture vs. Time in blanched samples.

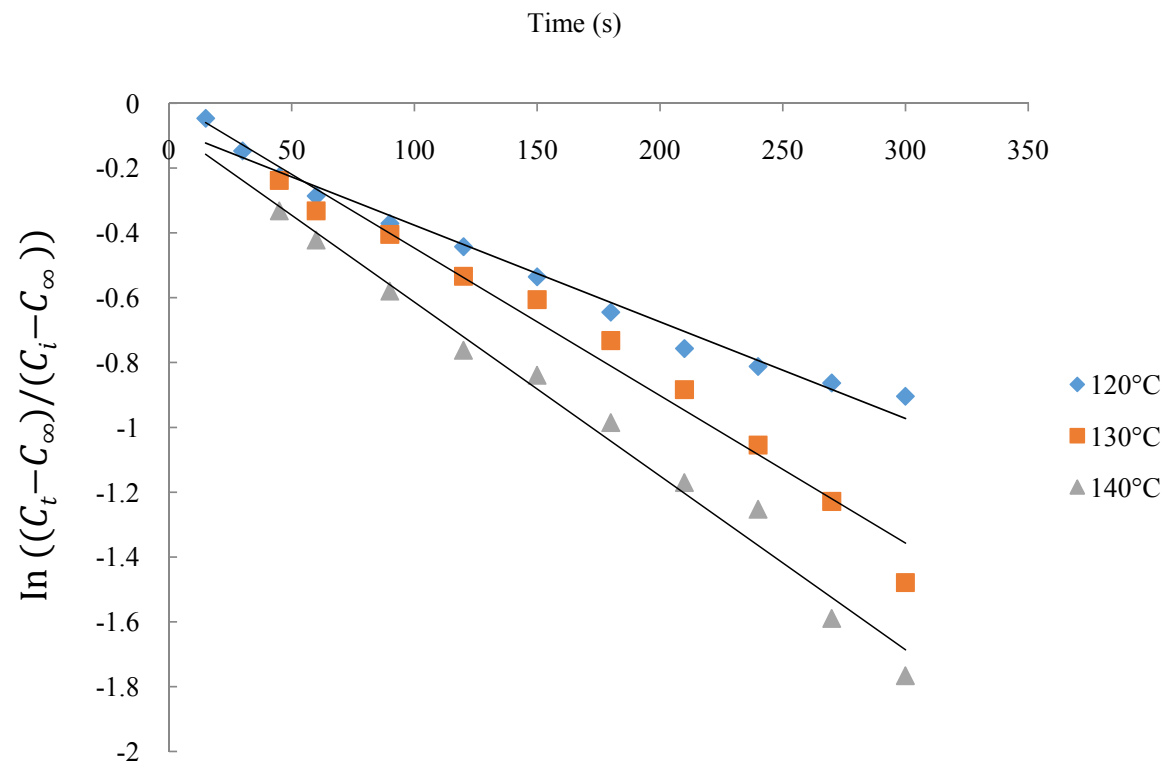

Fig 3. Linear sectionof the adimensionless relation Moisture vs. Timein control samples.

Table 1 reports the moisture diffusivity coefficient and the diffusion activation energy at different frying temperatures. It is observed that the diffusion coefficient augmented with increasing temperatures for all treatments. It is also shown that at temperatures of $140{ }^{\circ} \mathrm{C}$ the diffusion coefficient of the control samples was higher than in the blanched samples, but lower than the pectin-coated samples. This can be explained because the water loss rate was higher in the control fruit, but does not indicate that it was the treatment that lost more moisture. That is, there was a phase in which the moisture rate came out with greater speed than the other samples. Alviset al., [20]stated that rate of moisture lossis greater with the increase in oil temperature, as well as the effective diffusivity, since at higher temperature, higher porosity and consequently greater water diffusivity occur. 
Table 1. Diffusion coefficient and activation energy of Breadfruit

\begin{tabular}{|c|c|c|c|}
\hline Pre-treatment & Oil Temperature $\left({ }^{\circ} \mathrm{C}\right)$ & $D_{a}\left(m^{2} s^{-1}\right)$ & $E_{a}\left(k ~ m o l^{-1}\right)$ \\
\hline \multirow[t]{3}{*}{ Control } & 120 & $2.7356 \mathrm{E}-07$ & \multirow[t]{3}{*}{4.14} \\
\hline & 130 & $4.1947 \mathrm{E}-07$ & \\
\hline & 140 & $4.9242 \mathrm{E}-07$ & \\
\hline \multirow[t]{3}{*}{ Coating } & 120 & $2.3709 \mathrm{E}-07$ & \multirow[t]{3}{*}{14.05} \\
\hline & 130 & $2.736 \mathrm{E}-07$ & \\
\hline & 140 & $2.9180 \mathrm{E}-07$ & \\
\hline \multirow[t]{3}{*}{ Scalding } & 120 & $2.6444 \mathrm{E}-07$ & \multirow[t]{3}{*}{4.49} \\
\hline & 130 & $2.7356 \mathrm{E}-07$ & \\
\hline & 140 & $2.8268 \mathrm{E}-07$ & \\
\hline
\end{tabular}

Among the moisture transporting properties of the moisture diffusivity in a product, frying is the one that controls, since it defines the velocity of diffusion of liquid or steam in the product and also the velocity of evaporation and condensation. It has been found considerably that the moisture of various foods has varied due to the complex structure of the polymers in them (starch and protein) and their interaction with water[21]. Average values obtained for $\mathrm{D}_{\text {eff }}$ in the study by Alviset al., [20] in sweet potato frying (Ipomoea Batatas Lam), at the respective temperatures of 150,170 and $190{ }^{\circ} \mathrm{C}$, the diffusion coefficients were of $9.19 \times 10^{-7} \mathrm{~m}^{2} \mathrm{~s}^{-1}$, $10.7 \times 10^{-7}$ and $13.9 \times 10^{-7} \mathrm{~m}^{2} \mathrm{~s}^{-1}$ for uncoated samples and $9.52 \times 10^{-7} \mathrm{~m}^{2} \mathrm{~s}^{-1}, 12.3 \times 10^{-7} \mathrm{~m}^{2} \mathrm{~s}^{-1}$ and $15.3 \times 10^{-7} \mathrm{~m}^{2} \mathrm{~s}^{-1}$ for coated samples, being similar to those performed in this study.

In research conducted it has been found that the effective moisture diffusivity in the industrial cake dough system during baking of a cake was $9.9 \times 10^{-11} \mathrm{~m}^{2} \mathrm{~s}^{-1}-3.8 \times 10^{-8} \mathrm{~m}^{2} \mathrm{~s}^{-1}$ for the temperature of products from 33.1 to $126{ }^{\circ} \mathrm{C}$ [22], different from those reported in this study. But very similar to those reported by Dincer and Yildiz[23] for sausages, fried at $180{ }^{\circ} \mathrm{C}\left(1.31 \times 10^{-7} \mathrm{~m}^{2} \mathrm{~s}^{-1}\right)$. Differences can be attributed to the nature of the product, the process and the methods of determination used.

During the cooking of a cake made by Baik and Marcotte[22], the moisture diffusivity increased exponentially with temperature. Typically, moisture diffusivity in a solid material increases with porosity and moisture content. The samples of low porosity increased as the moisture content increased; while those of the samples of average porosity rose and fell with the increase of the moisture content. In this case, it is generally accepted that the water diffusivity in a porous medium is directly proportional to the porosity which decreases as the water content decreases. For convection drying of peach slices reported by Zhu and Shen, [24], $D_{\text {eff }}$ valuesvaried in the range of $5.60 \times 10^{-10} \mathrm{~m}^{2} \mathrm{~s}^{-1}$ to $1.33 \times 10^{-9} \mathrm{~m}^{2} \mathrm{~s}^{-1}$ at $60-80{ }^{\circ} \mathrm{C}$ with $0.003 \mathrm{~m}$ thickness and $0.946 \mathrm{~ms}^{-1}$ rate, in the range of $6.66 \times 10^{-10} \mathrm{~m}^{2} \mathrm{~s}^{-1}$ to $1.1350 \times 10^{-9} \mathrm{~m}^{2} \mathrm{~s}^{-1}$ between $0.423 \mathrm{~m} \mathrm{~s}^{-1}-1.120 \mathrm{~m} \mathrm{~s}^{-1}$ air velocity $0.003 \mathrm{~m}$ thickness and $70^{\circ} \mathrm{C}$.

\section{A. Activation energy of the moisture diffusion}

The activation energy $\left(E_{a}\right)$ was calculated by linear regression analysis on a semi-logarithmic graph between the moisture diffusivity and the inverse of the absolute temperature. The activation energy is a measure of the $D_{\text {eff }}$ temperature sensitivity. It is the energy necessary to initiate the diffusion of moisture inside the food. It has been found that $E_{a}$ is independent of moisture content. In this study it was observed that the treatment that reported higher $\mathrm{E}_{\mathrm{a}}$ was applied to pectin coating. In general, products having high sugar or pectin content, compact tissue structures and small specific surface area may have higher activation energy than those having low sugar or pectin content, porous structures and large surface area [16].

Nasiriet al., [25] reported an activation energy obtained from the Arrhenius representation for effective moisture diffusivity ranging from $18.42 \mathrm{~kJ} \mathrm{~mol}^{-1}$ to $23.84 \mathrm{~kJ} \mathrm{~mol}^{-1}$, for shrimp samples coated with flour paste during frying, similar to the sample coated in this study. The activation energy is an indication of the energy required to remove moisture from the inside to the outside of the dried product. This phenomenon may be due to the fact that the components, tissue structures and the specific surface area of the product have a significant effect on $E_{a}$. In addition, previous treatments can either change the physical properties of the sample cell structure or remove the wax layer on the surface of products that prevent the transport of moisture during drying, also have a significant effect on the activation energy of the products [16].

\section{B. Kinetic parameters of oil-uptake}

In Table 2 the parameters of specific oil absorption rate, activation energy and equilibrium oil content are observed. It is observed that as the frying temperature increases the equilibrium oil content is reduced in all treatments. In addition, the blanched sample reported the lowest oil content during all frying temperatures. It is also evident that the $\mathrm{k}$ of the control sample decreased at higher temperatures, different from the blanched treatments, which the specific rate decreased with increasing temperature. 
On the other hand, some authors reported that scalding at low temperatures (e.g. $\left.55-70{ }^{\circ} \mathrm{C}\right)$ before frying activates pectinesterase enzyme (PME) and the resulting reactions decrease porosity and thus reduce oil absorption. For the case of the coated samples, this parameter was increased with the temperature. Dueik and Bouchon[26] found that vacuum carrots and potato chips absorb about 50\% less oil than potato chips at atmospheric pressure, while vacuum fried apple chips reduce oil absorption by $25 \%$, but a considerable amount of oil is still being absorbed. It has been reported that starch gelatinization reduces oil absorption during frying [27].

Studies by Krokidaet al.,[17] stated that the values of the equilibrium oil content are higher for the smaller sample size. As regards the oil content rate constant, it decreases with the temperature increase, this is more tending towards higher thickness values. Several factors that affect oil absorption during frying are oil quality, composition, frying temperature, time and shape of the product, initial moisture content, initial interfacial tension, porosity and bark foods. During frying of snacks based on the chickpea flour, the moisture content of the fried product decreased and the oil content increased rapidly [28].

Table 2. Parameters of the kinetic model of Krokida

\begin{tabular}{|c|c|c|c|c|}
\hline Treatment & $\mathrm{T}\left({ }^{\circ} \mathrm{C}\right)$ & $\mathbf{O}_{\text {eq }}$ & $k\left(s^{-1}\right)$ & $\begin{array}{c}\text { ActivationEnergy } \\
\left(\mathrm{kJ} \mathrm{mol}^{-1}\right)\end{array}$ \\
\hline \multirow[t]{3}{*}{ Control } & 120 & 0.34 & 0.001 & \multirow[t]{3}{*}{-24.78} \\
\hline & 130 & 0.31 & 0.001 & \\
\hline & 140 & 0.23 & 0.0009 & \\
\hline \multirow[t]{3}{*}{ Blanching } & 120 & 0.25 & 0.0015 & \multirow[t]{3}{*}{-49.47} \\
\hline & 130 & 0.18 & 0.0006 & \\
\hline & 140 & 0.12 & 0.0003 & \\
\hline \multirow[t]{3}{*}{ Coating } & 120 & 0.29 & 0.0005 & \multirow[t]{3}{*}{-28.12} \\
\hline & 130 & 0.23 & 0.0007 & \\
\hline & 140 & 0.19 & 0.0007 & \\
\hline
\end{tabular}

In the case of pre-treated potato frying, Moyano and Pedreschi [29], for all cases and for both models studied, the specific rate $\mathrm{K}$ and $\mathrm{K}^{1}$ increased with the frying temperature, whereas the oil content of Oeq and $\mathrm{O}^{1}$ eq decreased with temperature. According to the results reported by Alvarez et al.,[30], found that during scalding and using high temperatures and short times (e.g., $97^{\circ} \mathrm{C}, 2 \mathrm{~min}$ ) before frying potato strips, resulted in a higher oil content than in fresh strips, which is undesirable for the acceptance of the product by the consumer. Debnath et al. [29] stated that, generally, the $\mathrm{O}_{\mathrm{eq}}$ values increased considerably as the frying temperature decreased for the three pre-treatments studied. The mass transfer coefficient of oil varied from $\left(0.056\right.$ to $\left.0.082 \mathrm{~s}^{-1}\right)$ and increased with the frying temperature of snacks prepared with chickpea flour and modified starch. Regarding the activation energy, the control sample presented higher energy than the other treatments. In this study gave negative results, i.e. this indicates that the rate of oil absorption decreased with increasing temperature.

Moyano and Pedreschi[29] stated that the higher frying temperatures lower the oil content and it can be seen that the effect of temperature at equilibrium or maximum value of oil content is much more sensitive in the case of control chips with an activation energy of $-10234 \mathrm{~J} \mathrm{~mol}^{-1}$. The dried slices were the least temperature-sensitive at an activation energy of $-2485 \mathrm{~J} \mathrm{~mol}^{-1}$, while the bleached was $-5999 \mathrm{~J} \mathrm{~mol}^{-1}$.

\section{CONCLUSIONS}

The equilibrium oil content was reduced as the temperature increased in all the studied cases, and was lower in the scaled samples. In all treatments the control, scalded and pectin coated samples, the moisture content decreased with increasing temperature. In contrast the diffusion coefficient was increasing with respect to the temperature. It was evidenced that the specific rate of oil absorption of the control sample decreased at higher temperatures, different from the blanched treatments, which the specific rate decreased with increasing temperature. In this study it was observed that the treatment that reported higher $\mathrm{E}_{\mathrm{a}}$ diffusion was applied to coating with pectin. On the other hand the oil absorption $\mathrm{E}_{\mathrm{a}}$ gave negative results.

\section{ACKNOWLEDGMENT}

The authors are grateful to the University of Cartagena for the financial supportto the project "Development plan for obtaining financial resources in support of the strengthening and sustainability" that was granted to the Research Group Nutrición, Salud y CalidadAlimentaria (NUSCA). 


\section{REFERENCES}

[1] D. F. Tirado, D. Acevedo, and P. Montero, "Secado de rodajas de fruto del árbol del pan mediante la técnica de Ventana Refractiva ${ }^{\circledR}, "$ Tecno Lógicas, vol. 19, no. 36, pp. 103-111, 2016.

[2] M. Farid and R. Kizilel, "A new approach to the analysis of heat and mass transfer in drying and frying of food products," Chem. Eng. Process. ProcessIntensif., vol. 48, no. 1, pp. 217-223, Jan. 2009.

[3] A. Halder and A. K. Datta, "Surface heat and mass transfer coefficients for multiphase porous media transport models with rapid evaporation," Food Bioprod. Process., vol. 90, no. 3, pp. 475-490, Jul. 2012.

[4] E. Roca, V. Guillard, B. Broyart, S. Guilbert, and N. Gontard, "Effective moisture diffusivity modelling versus food structure and hygroscopicity," Food Chem., vol. 106, no. 4, pp. 1428-1437, Feb. 2008.

[5] R. Khir, Z. Pan, A. Salim, B. R. Hartsough, and S. Mohamed, "Moisture diffusivity of rough rice under infrared radiation drying," LWT - Food Sci. Technol., vol. 44, no. 4, pp. 1126-1132, May 2011.

[6] J. Crank, The Mathematics of Diffusion. London, UK, 1979.

[7] M. Vasić, Ž. Grbavčić, and Z. Radojević, "Determination of the moisture diffusivity coefficient and mathematical modeling of drying,” Chem. Eng. Process. ProcessIntensif., vol. 76, pp. 33-44, Feb. 2014.

[8] E. Demirkol, F. Erdoğdu, and T. K. Palazoğlu, "Analysis of mass transfer parameters (changes in mass flux, diffusion coefficient and mass transfer coefficient) during baking of cookies," J. Food Eng., vol. 72, no. 4, pp. 364-371, Feb. 2006.

[9] S. Simal, A. Femenia, M. C. Garau, and C. Rosselló, "Use of exponential, Page's and diffusional models to simulate the drying kinetics of kiwi fruit," J. Food Eng., vol. 66, no. 3, pp. 323-328, Feb. 2005.

[10] J. Mir-Bel, R. Oria, and M. L. Salvador, "Influence of temperature on heat transfer coefficient during moderate vacuum deep-fat frying," J. Food Eng., vol. 113, no. 2, pp. 167-176, Nov. 2012.

[11] V. Dueik, M. C. Moreno, and P. Bouchon, "Microstructural approach to understand oil absorption during vacuum and atmospheric frying," J. Food Eng., vol. 111, no. 3, pp. 528-536, Aug. 2012.

[12] M. Rubnov and I. S. Saguy, "Fractal Analysis and Crust Water Diffusivity of a Restructured Potato Product During Deep-Fat Frying," J. Food Sci., vol. 62, no. 1, pp. 135-137, Jan. 1997.

[13] M. Mellema, "Mechanism and reduction of fat uptake in deep-fat fried foods," Trends Food Sci. Technol., vol. 14, no. 9, pp. 364-373, Sep. 2003.

[14] R. Williams and G. . Mittal, "Water and Fat Transfer Properties of Polysaccharide Films on Fried Pastry Mix," LWT - Food Sci. Technol., vol. 32, no. 7, pp. 440-445, Nov. 1999.

[15] AOAC, Official methods of analysis of AOAC International. AOAC International., 18th ed. 2005.

[16] H.-W. Xiao, C.-L. Pang, L.-H. Wang, J.-W. Bai, W.-X. Yang, and Z.-J. Gao, "Drying kinetics and quality of Monukka seedless grapes dried in an air-impingement jet dryer," Biosyst. Eng., vol. 105, no. 2, pp. 233-240, Feb. 2010.

[17] M. .Krokida, V. Oreopoulou, and Z. .Maroulis, "Water loss and oil uptake as a function of frying time," J. Food Eng., vol. 44, no. 1, pp. 39-46, Apr. 2000.

[18] Statgraphics, "Statpgraphics Centurion Statpoint technologies Inc." 2009.

[19] L. Guzman, D. Acevedo, and C. Granados, "Effect of blanching, osmotic dehydration and coating on the moisture loss and oil gaining in native potato chips pieces," Biotecnol. en el Sect. Agropecu. y Agroindustrial, vol. 10, no. 2, pp. 170-177, 2012.

[20] A. Alvis, A. González, and G. Arrázola, "Efecto del recubrimiento comestible en las propiedades de trozos de batata (Ipomoea Batatas Lam) fritos por inmersi??n. Parte 2: Propiedades termof??sicas y de transporte," Inf. Tecnol., vol. 26, no. 1, pp. 103-116, 2015.

[21] M. Sakin, F. Kaymak-Ertekin, and C. Ilicali, "Modeling the moisture transfer during baking of white cake," J. Food Eng., vol. 80, no. 3, pp. 822-831, Jun. 2007.

[22] O.-D. Baik and M. Marcotte, "Modeling the moisture diffusivity in a baking cake," J. Food Eng., vol. 56, no. 1, pp. 27-36, Jan. 2003.

[23] I. Dincer and M. Yildiz, "Modelling of thermal and moisture diffusions in cylindrically shaped sausages during frying," J. Food Eng., vol. 28, no. 1, pp. 35-44, Apr. 1996.

[24] A. Zhu and X. Shen, "The model and mass transfer characteristics of convection drying of peach slices," Int. J. Heat Mass Transf., vol. 72, pp. 345-351, May 2014.

[25] F. DehghanNasiri, M. Mohebbi, F. TabatabaeeYazdi, and M. H. Haddad Khodaparast, "Kinetic modeling of mass transfer during deep fat frying of shrimp nugget prepared without a pre-frying step," Food Bioprod. Process., vol. 89, no. 3, pp. 241-247, Jul. 2011.

[26] V. Dueik and P. Bouchon, "Development of Healthy Low-Fat Snacks: Understanding the Mechanisms of Quality Changes During Atmospheric and Vacuum Frying," Food Rev. Int., vol. 27, no. 4, pp. 408-432, Oct. 2011.

[27] G. Bingol, B. Wang, A. Zhang, Z. Pan, and T. H. McHugh, "Comparison of water and infrared blanching methods for processing performance and final product quality of French fries," J. Food Eng., vol. 121, pp. 135-142, Jan. 2014.

[28] S. Debnath, K. .Bhat, and N. .Rastogi, "Effect of pre-drying on kinetics of moisture loss and oil uptake during deep fat frying of chickpea flour-based snack food," LWT - Food Sci. Technol., vol. 36, no. 1, pp. 91-98, Feb. 2003.

[29] P. Moyano and F. Pedreschi, "Kinetics of oil uptake during frying of potato slices: Effect of pre-treatments," LebensmittelWissenschaftund-Tech., vol. 39, no. 1, pp. 285-291, 2006.

[30] M. D. Alvarez, M. J. Morillo, and W. Canet, "Characterization of the frying process of fresh and blanched potato strips using response surface methodology,” Eur. Food Res. Technol., vol. 211, no. 5, pp. 326-335, Oct. 2000.

\section{AUTHOR PROFILE}

Diofanor Acevedo Correa works as full-time professor at the University of Cartagena (Colombia). Dr. Acevedo completed his doctorate from the University of Valle (Cali-Colombia).Mr. Acevedo completed his bachelor in Food Engineering and Pharmaceutical Chemistry at the University of Cartagena.

Luis Alberto Gallo Garcia works as research assistant in the Research Group Nutrición, Salud y Calidad Alimentaria (NUSCA). Mr. Gallo-García completed his bachelor in Food Engineering at the University of Cartagena

Kevin José González Moreloworks as research assistant in the Research Group Nutrición, Salud y Calidad Alimentaria (NUSCA). Mr. González-Morelo completed his bachelor in Food Engineering at the University of Cartagena. 